\title{
The UN peacebuilding process: an analysis of its shortcomings in Timor-Leste
}

\author{
O processo de construção da paz da ONU: uma análise \\ de suas falhas no Timor Leste
}

http://dx.doi.org/10.1590/0034-7329201500103

RAMON BLANCO*

Rev. Bras. Polít. Int. 58 (1): 42-62 [2015]

On May $20^{\text {th }} 2002$, Timor-Leste became, under the auspices of the United Nations (UN), an independent state. The $\mathrm{UN}$ peacebuilding process there was the instrument deployed to deal with the international emergency that Timor-Leste had become over the years. The process of seeking to build a liberal peace ${ }^{1}$ in Timor-Leste is a process that sought to put an end to a long period of occupations and violence in the country (Richmond and Franks 2009, 83) and, simultaneously, to address issues of development and security in Timor-Leste. Due to the range, scope and depth of activities performed on the ground, employing nearly all the instruments at its disposal, the UN engagement with Timor-Leste "represented an important marker in the liberal statebuilding process" (Idem). Indeed, Timor-Leste, due to the unprecedented scope of UN engagement, is considered as a "test case" regarding peacebuilding processes (Suhrke 2001).

Now that the UN presence in Timor-Leste, in the form of a peace operation, ${ }^{2}$ have finished for more than a couple of years, one is in a privileged position to have a more comprehensive understanding about the UN peacebuilding efforts in Timor-Leste, especially its shortcomings. This is precisely the objective of this paper. It brings a comprehensive analysis of the UN peacebuilding process in Timor-Leste by highlighting its major shortcomings. Methodologically, the research for this paper is anchored fundamentally on primary sources regarding

\footnotetext{
Relações Internacionais e Integração at Universidade Federal da Integração Latino-Americana (Unila), Curitiba, PR, Brazil (blanco.ramon@gmail.com).

1 For more in this regards, see, for instance, David (1999), Richmond (2004, 2006, 2007), Newman et al. (2009), Paris (2010) and Taylor (2010).

2 Following the UN terminology, this paper uses the term "peace operations" to mean "[f]ield operations deployed to prevent, manage, and/or resolve violent conflicts or reduce the risk of their recurrence" (UN 2008, 98).
} 
the UN engagement with Timor-Leste. In order to operationalize its analysis, the research rests essentially on the combination of two methodological instruments: archival research and fieldwork (direct observation and interviews). Regarding the first instrument, the research examined relevant documents, mainly UN documentation—-resolutions, reports, and evaluations from the UN systembut also documents from other international organizations, non-governmental institutions, research centers and think-tanks, as well as national reports and legislation. In regards to the second methodological instrument, the fieldwork enabled the opportunity of first-hand observation of how the UN peacebuilding process has been consolidated and, simultaneously, provided access to key actors in the process. The fieldwork consisted mainly in qualitative semi-structured interviews and direct observation. The interviews for the research were conducted at three different sites: Dili, which comprises the vast majority of the interviews; Lisbon and, to a lesser extent, Brussels. The interviews in Dili were made between June and July of 2012, while the ones done in Lisbon were conducted in May 2012 and those in Brussels in September 2011. The number of interviews is $50 .^{3}$

The interviewing process benefited from the snowball effect and covered a widespread range of actors, both international and Timorese ones, representing a wide sort of spheres of the peacebuilding process in Timor-Leste. In regards to the actors interviewed, it was reached high and mid-level officials from international organizations, international agencies, state cooperation agencies, embassies, and international financial institutions. In addition, the research also included interviews with high and mid-level officials, both in office and former ones, of the Timorese state, members of local NGOs, along with Timorese academics. In regards to the spheres, the interviews covered the wide range of the fields that characterize the UN peacebuilding in Timor-Leste. Although these spheres are hardly differentiated on the ground, they can be characterized as: (1) the disciplinary sphere, which namely covers the police, the army, and the justice system; (2) the political and economic governance sphere; and (3) the social sphere. The fieldwork was also instrumental in allowing direct observation of the process. The research benefited very much from the fact that it was the parliamentary election period. This allowed a close observation of the campaigning period and the electoral process. Furthermore, the research was enriched by the fact that the author was able to be an international accredited electoral observer in the 2012 Parliamentary elections. The electoral observation proved to be very informative and insightful in the sense that provided the opportunity to observe part of the peacebuilding process that Timor-Leste was subject from within.

3 Since most, if not all, of interviewees are still active in the field (in Timorese politics, the UN or at a NGO), the author refrained himself from quoting them directly. This was done in order to preserve their identities and, therefore, not taking the risk of jeopardizing, in any way, either their careers or the author's future research in the field. The list with their names, dates and site of the interviews is kept in a personal archive and can be disclosed at the author's own discretion. 
In order to advance its analysis, the paper is structured around three sections. Firstly, the paper brings a very brief outline of scholarly debate around the UN peacebuilding efforts in order to frame its analysis. On its second section, the paper delineates the UN peace operations deployed to Timor-Leste bringing attention to the main elements of each of them. Finally, on its last section, the paper evinces the major structural shortcomings of the UN engagement with Timor-Leste and also brings to light some of structuring elements of the Timorese reality that were neglected by the UN peacebuilding effort in the country.

\section{A brief outline of the United Nation's peacebuilding debate}

The UN peace operations went through a lot of modifications throughout time. ${ }^{4}$ For instance, whereas during the Cold War a peace operation would be just a small military force aiming to monitor a ceasefire, or patrol a neutral territory between former combatants, usually acting as a buffer between two states (Newman et al. 2009, 5; Paris and Sisk 2009b, 4); from the end of the Cold War onwards, the UN peace operations incorporated civilians and activities ranging, for example, from strengthening law and order, elections, constitution drafting, to (re)building state institutions, to name a few. Due to its centrality in the international sphere, UN peace operations certainly incite scholar's debate and, consequently, a lot have been discussed about it. Superficially, three main lines of arguments within the literature can be identified (Chandler 2008, 2-3; Paris and Sisk 2009b, 12-13; Paris 2010). In essence, they argue that: (1) the process is too interventionist/ambitious (Englebert and Tull 2008), and that the intervention should not happen in the first place (Luttwak 1999); (2) the whole enterprise lacks commitment/resources (Chesterman 2005), and more should be done (Ignatieff 2003; Fearon and Laitin 2004); and (3) focus should be placed on the "coordination problem" among the different actors and the wide range of resources deployed (Paris 2009).

However, many other aspects were elucidated by those studying peace operations. This was the case, for instance, of issues like: some elements of success/ failure of such practice (Gürkaynak et al. 2009; Lijn 2009); their mixed records (Doyle and Sambanis 2006; Fortna 2008); the interrogation whether they in fact have a positive effect in avoiding the recurrence of violent conflicts (Gilligan and Sergenti 2008); their political economy (Pugh 2005); the underlying paradoxes/ contradictions of this enterprise (Paris and Sisk 2009a); or even the elucidation that this process might serve as an instrument of containing conflict-affected people in their own countries (Duffield 2001). Furthermore, there is also, for example, the effort of putting these processes into a more historical perspective. Consequently,

4 Due to the scope of this paper, this section does not intend to be an exhaustive analysis of the UN peace operations' characteristics, their theoretical underpinnings and transformations throughout time. This was already developed somewhere else (Blanco 2014). See also, for instance, Newman et al. (2009), Paris and Sisk (2009b) and Kenkel (2013). 
there are analysts who attach the "peace" efforts in Afghanistan, Bosnia and Kosovo, for instance, to imperial practices (Ignatieff 2003; Encarnación 2005). Not by coincidence, there are those who draw parallels between current peacebuilding practices and the mission civilizatrice of the past (Paris 2002).

Another element that is present in the debate is the underlying ideological assumptions of the UN peacebuilding. It is Roland Paris (2004) and Oliver Richmond (2007), for instance, who delineate the theoretical cornerstones of current peace efforts, evincing their distinct liberal tone. Following this path, Beate Jahn (2007a, b) also evince their solid roots in the liberal ideology. To Kirsti Samuels and Sebastian Einsiedel (2003), there are strong underlying assumptions in peacebuilding efforts, "particularly the notion that a Western-style liberal democracy is the outcome sought" (Ibidem, 3). Therefore, what is perceived is a "one-sizefits-all" model regarding peacebuilding that is indiscriminately applied throughout every post-conflict scenario. Oliver Ramsbotham calls it a "standard operating procedure" (2000, 170). For Marina Ottaway (2002), this model is underpinned by a series of prescriptions that "in essence list the institutions and processes that need to be in place in a modern, Weberian, democratic state" (Ibidem: 1009).

It was already evinced, also, not only that the process represents a specific social engineering, but its destabilizing effects and possibilities of reproducing the very sources of violent conflicts (Paris 2004). In this regards, some authors focus, for example, in the correlation between post-war elections and the occurrence of violence. Jack Snyder (2000) explores this hypothesis when evinced that democracy promotion, in early stages of the democratization process, might enhance, rather than reduce, the probability of violent conflicts. For Paris (2004), the rapid move to elections, before having proper institutions in place, is what leads to violence. Edward Mansfield and Jack Snyder (2005) add that the postwar electoral process introduces new kinds of uncertainties and that might leave the recovering society vulnerable to violence.

Other analysts focus more on the local context. Beatrice Pouligny (2006), for instance, seeks to understand how local individuals and groups perceive their relationship with UN missions. Furthermore, Roger Mac Ginty (2008) also problematizes the local context when focusing on local peacemaking practices. He observes indigenous peacemaking efforts and interrogates how those can relate to Western forms of peacemaking. Other observers evince, for example, the failure of such missions to engage with the local people. Richmond and Franks, for instance, expose lack of engagement of UN missions with local cultures, identities and everyday life (Richmond 2009; Richmond and Franks 2009). More recently, other analysts problematize the question of "political hybridity." They illustrate the combination of "elements of the introduced Western models of governance and elements stemming from local indigenous traditions" (Boege et al. 2008, iii; Boege et al. 2009, 2010) and, consequently, illuminating the "hybrid political orders" that emerge from such interaction between internationals and locals. 
Having this whole debate in mind, one is in a privileged position to pursue a comprehensive analysis of the UN peacebuilding process carried out in TimorLeste. Since Timor-Leste represents a fundamental case of UN peacebuilding processes, Timor-Leste emerges as natural case for pursing a rigorous analysis of the UN post-conflict reconstruction efforts. This is precisely the direction that this paper now takes.

\section{The United Nation's peace operations in Timor-Leste: an overview}

The UN relationship with Timor-Leste became deeper only in 1999 when the Timorese tragedy became internationally visible. Since 1999, the UN deployed five consecutive peace operations to Timor-Leste: UNAMET (1999), UNTAET (1999-2002), UNMISET (2002-2005), UNOTIL (2005-2006) and UNMIT (2006-2012). ${ }^{5}$ There is no other case with such level of engagement. Collectively, these peace operations constitute a project "intended to end civil war and years of foreign oppression through the creation of liberal peace and the construction of an independent liberal democratic state" in Timor-Leste (Richmond and Franks 2009, 83).

In 1999, after a tripartite negotiation with Portugal and Indonesia, the UN was entrusted to organize a referendum in Timor-Leste regarding their political future. In this referendum, the Timorese would vote on an Indonesian proposal regarding a comprehensive autonomy. Rejecting the proposal, the Timorese would indicate that they have chosen their independence. Consequently, on June $11^{\text {th }} 1999$, the Security Council (SC) (S/RES/1246) established the United Nations Mission in East Timor (UNAMET) "to organize and conduct a popular consultation" (S/RES/1246, 2), which should be based on "a direct, secret and universal ballot" (Idem). The mission was initially mandated to last until August $31^{\text {st }} 1999$, but ended up being extended twice until November $30^{\text {th }} 1999 .{ }^{6}$

Considering the violence perpetrated throughout the Indonesian occupation years and the crescent violent spiral in the prior days to the voting, the actual day of the vote, on August 30 1999 was relatively calm (Magalhães 2007, 478; Kingsbury 2009, 72). Notwithstanding the violence campaign perpetrated by the pro-autonomy militias, with the tacit consent of the Indonesian army, the consultation process had an outstanding voter turnout of $98.6 \%$ (Martin 2001, 160). The result was an unquestionable indication of the Timorese desire for independence: $78.5 \%$ rejected the autonomy proposal (S/1999/944).

Following the referendum, the security situation deteriorated drastically. The pro-autonomy militias and the Indonesian military, supported by the non-action

5 Timor-Leste was also subject to two multilateral international interventions: INTERFET (1999-2000) e ISF (2006-2013).

6 The extensions were (S/RES/1257; S/RES/1262). 
of the police, started a "scorched earth" campaign aiming to spoil the bases of any possibility of a viable independent Timorese state (Kingsbury 2009, 73). The first half of September was stage of a systematic policy of disappearances, rapes, murders, forced dislocations and all sorts of destruction of infrastructures and houses (Teles 1999, 411). An estimate of two thousand Timorese were killed, around 230,000 were forced to flee to West Timor, other several hundred thousand were internally displaced, and more than $70 \%$ of the territory's infrastructure was destroyed (Beauvais 2001, 1103; Kingsbury 2009, 73).

This massive violence led to a huge international outrage (Kingsbury 2009, 74) and to the understanding that the most effective means of a rapid response would be a UN-sanctioned multilateral intervention (Martin and Mayer-Rieckh 2005, 131-32). Under a great amount of pressure, Indonesia agreed to an international intervention force and, on September $15^{\text {th }}$, the SC (S/RES/1264), authorized the deployment of the International Force in East Timor (INTERFET), which controlled the violence in a matter of weeks (Beauvais 2001, 1103). However, "[a]part from improvements in the security situation in Dili, the general security situation in East Timor remain[ed] poor" (Ibidem; Paragraph 11). Moreover, the "civil infrastructure had been seriously degraded and where there was no effective civil administration” (Ibidem; Paragraph 22).

Aiming to address this situation, and to initiate the process of (re)building the Timorese state and infra-structures, the SC (S/RES/1272) created the United Nations Transitional Administration in East Timor (UNTAET). The mission would be responsible for several activities such as: (1) to provide security and maintain the law; (2) to assist in the development of civil and social services; (Idem); among others. However, its main objective was to create the Timorese state, its political institutions and to assist it towards its legal independence. Unprecedentedly, UNTAET was "endowed with overall responsibility for the administration of East Timor and will be empowered to exercise all legislative and executive authority, including the administration of justice" (Idem).

Before the Timorese independence, the SC established (S/RES/1410) the United Nations Mission of Support in East Timor (UNMISET), which was responsible for assisting the development of the newly independent Timorese state by supporting the administrative structures, providing interim law enforcement and contributing to the Timorese external and internal security (Idem). The mission was initially mandated to last until May $20^{\text {th }} 2003$. However, due to the very unstable security environment, UNMISET was extended three times. ${ }^{7}$ In 2005 , the environment on the ground was still violent and some alarming challenges still persisted, such as: (1) Timor-Leste was still far from self-sufficiency; (2) the severe fragility of Timorese public administration; and (3) the "formidable challenges" that the national police still faced regarding its structuring (S/2004/888: 14).

7 The extensions were (S/RES/1480; S/RES/1543; S/RES/1573). 
Notwithstanding, the UN presence in Timor-Leste was scaled down in 2005 and UNMISET ended on May $20^{\text {th }} 2005$. However, the UN presence continued to be felt in Timor-Leste in terms of a political office. On April $28^{\text {th }} 2005$, the SC (S/ RES/1599), established the United Nations Office in Timor-Leste (UNOTIL), whose main objective was to consolidate the activities carried out by UNMISET.

Due to the fragile situation on the ground, UNOTIL's mandate was extended three times. ${ }^{8}$ Notwithstanding, UNOTIL represented the process of phasing out of the UN in Timor-Leste. However, by neglecting crucial elements of the Timorese reality, which will be further discussed in the next section, this process culminated on a violent crisis in 2006 and 2008. In less than four years of an independent Timor-Leste and nearly less than a month for UNOTIL's end, the Timorese police and army, two of the fundamental pillars of the UN peacebuilding process in Timor-Leste, clashed and, on April-May 2006, Timor-Leste experienced another wave of violence. As a result, the state institutions, including the police and the armed forces, simply melted, 38 people were dead, more than 1,650 houses in Dili were destroyed, and nearly 150,000 people became internally displaced (ICG 2008, 3).

Reacting to this humanitarian catastrophe, the UN sanctioned the deployment of the International Stabilization Force (ISF). However, the violence continued. In fact, more people died between August 2006 and February 2007 than during the crisis itself (ICG 2008, 3). The UN Secretary General saw the crisis as a "complex one with political, institutional, historical, social and economic dimensions" (S/2006/628: 8). In reaction to the grave situation, the SG (S/2006/628) recommended the establishment of a multidimensional integrated mission-the United Nations Integrated Mission in Timor-Leste (UNMIT). The mission's mandate was extremely vast and aimed to: (1) (re)construct the state institutions, as well as enhance their capacity; (2) assist the government and the institutions to enhance their democratic-governance culture; (3) restore and maintain public security, including law enforcement, in the country; (4) reconstruct the national police and army; (5) facilitate relief and recovery assistance; among many other dimensions (Idem).

Unsurprisingly, the fragile situation on the ground remained and UNMIT's mandate was extended and restructured several times. ${ }^{9}$ This happened due to: (1) an unsecure and violent environment in Timor-Leste (including gang violence and an attack, on February 2008, against the President and the Prime Minister); and (2) two major election seasons for the Parliament and the Presidency, scheduled to take place. In the first election season, from April to June 2007, José RamosHorta was elected President, in a second round, with nearly $70 \%$ of the votes. ${ }^{10}$

8 The extensions were (S/RES/1677; S/RES/1690; S/RES/1703).

9 The extensions were (S/RES/1745; S/RES/1802; S/RES/1867; S/RES/1912; S/RES/1969; S/RES/2037).

10 For the results of the 2007 presidential elections, see STAE (2007b). 
On the Parliamentary elections, Fretilin, led by Mari Alkatiri, had around 29\% of the votes. ${ }^{11}$ On the second election season, during the first semester of $2012,{ }^{12}$ it was Taur Matan Ruak who was sworn in as President of Timor-Leste with nearly $60 \%$ of the votes. ${ }^{13} \mathrm{~A}$ few months later, during the Parliamentary elections, the party led by Xanana Gusmão won with nearly $36 \%$ of the votes. It was only after Xanana Gusmão was sworn in as Timor-Leste's President, that UNMIT, on $31^{\text {st }}$ December 2012, ended its mandate.

\section{The shortcomings of the UN peacebuilding in Timor-Leste}

From this brief overview, one accurately concludes that the UN had a comprehensive engagement with Timor-Leste. Some analysts argue that the UN had to literally "invent" Timor-Leste (Traub 2000, 74), meaning that it had to build Timor-Leste from scratch. Unsurprisingly, such engagement is presented as a success case by the UN (Goldstone 2004, 83). Due to the depth of the UN engagement - the number of missions (and their several extensions), their duration, the range of peace instruments deployed (from peacemaking to peacebuilding, passing by the peace enforcement and peacekeeping), and the depth of the activities performed - the appearance of Timor-Leste as a successful case is fundamental to the organization. Otherwise, the whole UN conflict-resolution rationale, its peacebuilding approach, and its own reputation of as a conflict-transformation actor, would be severely in check. Therefore, for UN's own sake, Timor-Leste has to be perceived internationally as a successful case.

Nevertheless, such superficial appearance does not resist a rigorous analysis. The process left fragile foundations in regards to the peace built in Timor-Leste. The mere occurrence of the violent events in 2006 and the murder attempt to the Timorese President and Prime-Minister in 2008, after a comprehensive UN engagement, is a very strong indicator of such fragility. Moreover, although the UN remained for more than a decade in Timor-Leste, the Timorese socio-economical indicators are still very worrying. For instance, that Timor-Leste still have a very low Human Development Index (HDI) (UNDP 2014, 162). In fact, 49.9\% of the Timorese still live under the national poverty line (Ibidem: 181). Although some analysts argue that "poverty breeds insecurity" (Rice 2007, 31), the direct connection between poverty and violent conflicts is misleading. ${ }^{14}$ Notwithstanding, such context might be disturbing because in this severe environment, where the youth unemployment is around 15\% (UNDP 2014, 201), and probably higher

\footnotetext{
11 For the results of the 2007 parliamentary elections, see STAE (2007a).

12 The Presidential elections took place on March-April 2012 (the first round on March $17^{\text {th }}$ and the second round on April 16 ${ }^{\text {th }}$ 2012). The Parliament elections took place on July $7^{\text {th }} 2012$.

13 For the results of the 2012 presidential elections, see STAE (2012).

14 For the argument linking poverty and violence, see Miguel (2007) and Rice (2007). For a counter-argument, see Sen (2008).
} 
among urban youth, the martial gangs can become very attractive to the youth, which can potentially be very destabilizing.

In addition to the limitations of the very notion of peace operationalized by the UN in Timor-Leste, the liberal peace, ${ }^{15}$ the fragility of the foundations left by the UN peacebuilding process is underpinned by two axes: (1) the structural limitations of such engagement; and (2) the negligence, by the UN, of fundamental elements of the Timorese reality. The first axis is related to the structural limitations of the very peacebuilding process, which had several shortcomings from its very beginning. The first is the configuration of UNTAET and its key internal structural contradictions. In addition to the lack of collaboration, and even competition, between the Department of Political Affairs (DPA) and the Department of Peacekeeping Operations (DPKO), one can certainly argue that the tools assembled by the UN were inadequate to the task. UNTAET was essentially a state-building mission but it was equipped with peacekeeping tools, which is definitely contradictory (Suhrke 2001, 1).

Secondly, UNTAET had no structure to accommodate the Timorese participation in the decision-making processes (Suhrke 2001). Since the UN was mandated to "assist" the Timorese in their independence process, the lack of a structure to incorporate the Timorese voice was a fundamental shortcoming. Paradoxically, an engagement that would aim to support their independence prevented, sometimes "methodologically" in the words of Jarat Chopra a former Head of the Office of District Administration for UNTAET, the Timorese participation $(2002,981)$. Consequently, the failure to incorporate the Timorese participation "from the outset put UNTAET on a difficult course vis-a-vis the local population" (Suhrke 2001, 2) and ended up marginalizing a whole set of Timorese political experience, history, culture and needs (Richmond 2011, 87). The prevention of the Timorese participation is also observed in the very language on which the laws were written by UNTAET. Despite the wide linguistic variety of Timor-Leste, the Tetum functions as a sort of a lingua franca in the country (Carvalho 2001, 65). Nevertheless, very few legislative instruments were written in Tetum. The legislation promulgated by the UNTAET was available in English and Portuguese, and some in Indonesian. Although the Portuguese language played a key role in the genesis of the Timorese national identity and regarding the resistance movement (Ibidem: 70), the use of the Tetum is more widespread among the population. However, this fact was neglected by UNTAET, which ended up blocking the Timorese from having a more active role in a fundamental pillar of any country—its laws.

While analyzing the UN intervention in Timor-Leste, José Manuel Pureza and other researchers (Pureza et al. 2007) evince some structural shortcomings on different dimensions of the process, such as the military/security and political-

15 For a critique about the implementation of the liberal peace in Timor-Leste, see Richmond and Franks (2008). 
constitutional dimensions. On the first dimension, they evince that the expeditious manner of incorporating former rival combatants on the police and the army generated a tension between the two (Ibidem: 23). In fact, the uncertainty regarding the status of Falintil (Forças Armadas de Libertação e Independência de Timor-Leste), the armed dimension of the Timorese resistance, delayed the security sector reform. Later, it was decided for the establishment of the Timorese Defense Force with Falintil as its nucleus (Martin and Mayer-Rieckh 2005, 134). Those who were not recruited would be demobilized though the Falintil Reintegration Assistance Programme (FRAP). Nevertheless, resentments with the selection process generated instability within the organization and a number of security incidents among former Falintil members (Idem). Consequently, by the independence day, neither the police nor the army could fully perform the public security and the defense of the country (Ibidem: 135). On the political-constitutional dimension, Pureza $(2007,20)$ sheds light on the fact that the official language and the judicial system were sources of conflicts between the internationals and the Timorese. Whereas the former advocated for the use of the Indonesian language, or even the English, and the use of the common law, the latter advocated for the use of Portuguese and a civil model. This point led also to contradictions regarding the training of police and judicial authorities. Depending where they received the training, Portugal or Australia, they received a whole different training. (Ibidem: 23). Indeed, "the administration of justice was seriously inadequate (...) there was no coordinated or comprehensive strategy to develop the rule of law sector" (Martin and MayerRieckh 2005, 137).

The second axis regarding the fragility inherent to the UN peacebuilding process in Timor-Leste has to do with the neglect, by the organization, of fundamental strands of the Timorese reality. The mere occurrence of the 2006 crisis is the most emblematic example of this. ${ }^{16}$ In a nutshell, the 2006 crisis started when 159 Timorese soldiers signed a petition, to President Xanana Gusmáo, complaining about discrimination — particularly in regards to, salaries, promotions and accommodation-against westerners Timorese (Loromonu in Tetum) and favoring easterners Timorese (Lorosae in Tetum) (ICG 2008, 2). This group became known as the "peticionários" (petitioners in Portuguese). However, due to the mismanagement of the crisis, the situation rapidly scaled to an open conflict between the police and the army, culminating in a "gun battle" between the two on May $25^{\text {th }} 2006$ in and around the police headquarters in Dili (CIGI 2009, 3). As aforementioned, the crisis not only shattered the Timorese state apparatus, including the police and the army, but also left the country in a calamitous situation of drastic proportions on the humanitarian, political, institutional, historical, social and economic dimensions.

16 For a comprehensive account of the crisis, see Curtain (2006), ICG (2006, 2008), Kingsbury (2009, 138-53) and Richmond and Franks (2009, 89-93). 
The fact that the crisis was merely the surface of other deeper intertwined multi-level strands of the Timorese reality that were neglected, or at least underestimated, by the UN peacebuilding process evinces precisely its fragility. Remarkably, these strands are intrinsically related to fundamental dimensions of the reconstruction process-Disarmament, Demobilization and Reintegration (DDR), Security Sector Reform (SSR), and the political environment. They are: (1) the poor reintegration process of the combatants of the former guerrilla who was not incorporated in the army; (2) the structural dissatisfactions/divisions present within the armed forces; (3) the tense relationship between the police and the army; and (4) the grievances/differences among the Timorese political elite; to mention a few.

The first strand is related to the process of reintegrating former combatants into the society. As aforementioned, in Timor-Leste, the army (F-FDTL, FalintilForças de Defesa de Timor-Leste in Portuguese) has its origins in the transformation of Falintil into a regular armed force. ${ }^{17}$ Nevertheless, not all Falintil veterans were incorporated and several were left unemployed (ICG 2006). Those who were left out of the force received a small financial assistance ${ }^{18}$ in order to reinitiate their lives as civilians. This reinsertion was more than difficult and the money was rapidly spent. These men were for 25 years in the jungle fighting a resistance war and certainly had difficulties in becoming fisherman or owning a small business. When that money was over, many of them started to regroup; obviously, outside the security framework of the Timorese state. In addition, a deep resentment emerged when these former combatants, which were not incorporated in the military, saw that many of the police officers that were being recruited worked for the Indonesian army of police force during the occupation, while they, who fought for the Timorese independence, were unemployed (Idem).

A second strand of the Timorese reality that was neglected by the UN has to do with another fundamental part of UN peacebuilding process in the countrythe Security Sector Reform (SSR). More precisely, it results from tensions within the army that were increasing for some time. Damien Kingsbury $(2009,142)$, for instance, remembers a long-standing disquiet within the F-FDTL regarding several issues, such as: (1) their status vis-à-vis the police; (2) the general pay/conditions of the organization; (3) its lack of a clear purpose; and (4) a disappointment with the civilian politics. In addition, there were also tensions and divisions within the F-FDTL that dated back to the guerrilla time and the perceived role that each person had during the resistance. The division had to do with the perceived degree of resistance to, or connivance with, the Indonesian occupation based on geographic distinctions, which divided the people between Lorosae (easterners in Tetum) and Loromonu (westerners in Tetum).

17 The very name of the Timorese armed force, Falintil-Forças de Defesa de Timor-Leste (F-FDTL), is preceded by the name of the armed arm of the Timorese resistance-Falintil.

18 The amount was US\$ 550 and it was part of the FRAP program. 
This division, which was not anchored within the Timorese society, was based on the assumption within the army that those who were on the western side of the country, and therefore nearer to Indonesia, had a less prominent participation within the resistance movement and their participation was less confrontational than those who were on the eastern side of the country, who had a more confrontational approach towards the Indonesian occupation and, therefore, suffered more during the Indonesian rule (Kingsbury 2009, 145-46). This was a false dichotomy in the sense that "easterners" and "westerners" both resisted and were co-opted. Yet, this was something that was claimed by the soldiers, especially by the "western" soldiers (the majority of those recruited) in regards to the "eastern" F-FDTL leadership (Idem). Considering that the Timorese military force was the conversion of the former independence guerrilla force (Falintil) into an army force, this assumption was something that could easily lead to deep tensions. Indeed, this was exactly what occurred. This assumption led to concrete dissatisfactions which had been externalized for a while in Timor-Leste but were downplayed. They include, for instance: (1) on December 2003, 42 soldiers were discharged after complaining about unfair dismissals, travel distances and poor communications. There was a presidential commission, on August 2004, that suggested some improvements on these matters but they were not implemented; and (2) on 26 February 2005, there was a group of soldiers which started to raise some issues regarding discrimination directly with the President. Indeed, their complains were similar to the ones made, on January 2006, by the petitioners, which was the trigger of the 2006 crisis (ICG 2008, 2).

The third strand neglected during the peacebuilding process is also related to SSR - the strained relationship between the armed forces and the police. Firstly, one should not forget the backbone of each organization. Whereas the police had several former Indonesian police officers, and even military, in its organization, the army had as its very core former Timorese guerrilla men. Therefore, there were in Timor-Leste two organizations, that due to their ontology were armed, in which there were people who fought on different sides during the Indonesian invasion/occupation and the Timorese resistance period. Additionally, there were no concrete actions to approximate both institutions (ICG 2008, 2). As anecdotal as it may be, in the eyes of the US State Department, the only actions that aimed at improving the relationship between the police and the army were a series of high-profile goodwill meetings and a football match that the President was the referee (Idem). Therefore, it is clear that having two, potentially rival, armed state apparatus, in addition to limited efforts of narrowing their distance and making them collaborate with each other, is the very recipe for a severe instability, to say the least.

In fact, this led to a deep-rooted tension between both organizations that was externalized through many violent situations, which, in turn, feedback the 
tension. Indeed, although this tension exploded in the form of the violent events of 2006, the crisis was in fact the culmination of a series of incidents that exposed this deep tension between the Timorese army and the police (ICG 2008). This tension had grown over the previous years with some incidents, such as: (1) on September 2003, the alleged assault on soldiers by a group of police officers which led to a confrontation at the police station in Dili; (2) on January 2004, clashes during a game of volleyball led to the detention of some police officers by soldiers in Los Palos; (3) on December 2004, soldiers looted the police station in Becora, where one of their officers was detained and allegedly mistreated (Ibidem: 2).

The fourth strand neglected is related to another fundamental part of the UN peacebuilding process - the political environment. The UN simply neglected a significant part of the Timorese political history. The 2006 crisis might be also understood as grievances and differences, between Falintil and Fretilin, which dates back to the times of the resistance, ${ }^{19}$ being brought into the government politics. During the crisis, it was evident that part of the political and the security elite saw it as a political opportunity to "augment their own claim to power, vent their frustrations, or indeed protect themselves" (ICG 2006, i; Richmond and Franks 2009, 97). Superficially, the beginning of the crisis, the dismissal of the soldiers in March 2006, might be understood as part of a power struggle between the Prime-Minister, Mari Alkatiri, and the President, Xanana Gusmão (ICG 2006, i). It could be seen as an attempt to both destabilize the Fretilin's government, which was led by Alkatiri, and the Xanana's ascendance over the military, since most of the army was personally loyal to him (he was the commander of the Falintil during the resistance).

The Prime-Minister and the President certainly had their differences. However, these were part of a larger split between Falintil's commander, Xanan Gusmáo, and the Fretilin's central committee. This difference is rooted in both political and ideological disputes within the resistance movement. The origin of these disputes may be found in early 1980s. Until that time, the politics was the major pillar of the resistance, which made Fretilin's central committee the resistance's most important body. From 1981 onwards, the fighting increased in importance and superseded the politics. Therefore, Xanana Gusmão took a larger role in the decision-making (ICG 2006, 3). He took some decisions that were far from popular among the hardliners of Fretilin, for instance: (1) to initiate negotiations with the Indonesians; (2) to reach out to the Catholic Church and to other parties; and (3) to abandon Marxism in order to increase the united front (ICG 2006, 3). In 1984, a split took place-some senior members of Falintil, that were also members of the Fretilin's central committee, tried a failed a coup against Xanana Gusmão. Still in 1984, Xanana Gusmáo, made another decision that was

19 For a more detailed account of these splits, see, for instance, ICG (2006, 2-5). 
badly received by the Fretilin's central committee which led to another split-he proposed the dissociation of the Falintil from the Fretilin, which was only accepted on December $7^{\text {th }} 1987$ (Ibidem, 3-4). This dissociation in practice meant that the political side of the resistance was concentrated in the diaspora, with pivotal members of the central committee based in Angola and Mozambique, and its armed side remained in Timor-Leste and loyal to Xanana Gusmáo. This might be seen as a built-in divide between Fretilin and the military, and consequently Xanana Gusmão (ICG 2006, 4). In fact, this division had profound implications for the Timorese politics after its independence and still has repercussions nowadays. ${ }^{20}$

Notwithstanding all these elements, that are the basis of the fragility of the peace built in Timor-Leste, the whole construction of the Timorese state was portrayed as a success by the UN (Goldstone 2004, 83). However, what was celebrated on May 2002 was in fact a "state that existed only in name and the substance of the newly created state was indeed fantasy" (Richmond and Franks $2009,93)$. This interpretation of the Timorese reality is closely connected with the idea of a "phantom state" developed by David Chandler (2006). For him, this kind of situation occurs when it is perceived that a state may have some governance and administrative structures but it is not endowed with the political will of a society. It might have international legal sovereignty, but their policymaking are extensively controlled and supervised by international institutions (Ibidem: 43-44). Additionally, this links to the Christopher Bickerton's notion of the state-building process as a state-failure process. For him, state-building, while neglecting fundamental strands of the local environment and relegating the local population to a passive role of merely receiving institutions built, is indeed removing the popular will from the political process of their creation. Consequently, the institutions created are not deep-rooted in their societies. As a result, state-building, while building institutions with few social or political foundations, in fact creates institutions with very weak basis and that constantly need the international support to endure (Bickerton 2007, 93, 100). It is precisely this scenario that is perceived when analyzing the UN engagement with TimorLeste. Indeed, the very fact that the aforementioned strands were neglected, that the crisis happened, and that the Timorese institutions simply disintegrated during the events supports the understanding that the UN peacebuilding process, in Timor-Leste, did not lead to a sustainable peace in the country. On the contrary, such process might be understood as a state-failure process which built a kind of peace that has a very fragile basis.

20 Indeed, it is not hard to hear in Timor-Leste that the country is only stable when there is understanding between its three big figures: Xanana Gusmão, Mari Alkatiri, and José Ramos-Horta. Otherwise, there is potential for instability. 


\section{Conclusion}

This paper discusses the UN peacebuilding process in Timor-Leste. Firstly, it briefly outlines the scholarly debate around the UN peacebuilding efforts. Then, it presents a panoramic view of the UN peace operations deployed to Timor-Leste by clarifying their main elements and characteristics. In addition, the paper evinces that the fragilities of the foundations left by such process is anchored on two fundamental axes: (1) structural limitations of such engagement and (2) the negligence, by the UN, of fundamental elements of the Timorese reality. Regarding the first axis, the paper sheds light on the some structural shortcomings of the UN peacebuilding process in Timor-Leste. While discussing such limitations, the paper focuses on the internal shortcomings of the reconstruction process, on the marginalization of the Timorese in regards to the decision-making of the peacebuilding process, and also the deficiencies of dimensions, such as, the military/ security and political-constitutional. Finally, this paper delineates several strands of the Timorese reality which were neglected, or at least underestimated, by the UN during its peacebuilding process in Timor-Leste. They were at the basis of the 2006 crisis. Through the delineation of them, the paper evinces that the UN overlooked fundamental dimensions of the Timorese reality. This leads to the apparent contradiction that, in Timor-Leste, the UN state-building process ended up being, in fact, a state failure process, which sheds light to the fragility of the peace built. However, paradoxically, the appearance of Timor-Leste as a successful case is fundamental to the UN. In order to legitimize its peace operations to a broader audience and itself as an international actor, fundamental to the conflict resolution throughout the globe, Timor-Leste has to appear internationally as a successful case. Nevertheless, it is precisely the rigorous analysis of this process that allows the clarification of its limitations and, most importantly, opens of the space for its structural reproblematization, which might be the first step towards the emergence of a sustainable peace at post-conflict scenarios.

\section{Acknowledgement}

The research for this paper was funded by the Portuguese Foundation for Science and Technology (FCT) - SFRH/BD/43498/2008, by the European Union under a COST Short Term Scientific Mission - ECOST-STSMIS0805-050911-007628, and it was also conducted within the framework of the project "Peacebuilding and Sustainable Peace: UN Missions in TimorLeste and Portugal's Contribution", also funded by the FCT - PTDC/CPJCPO/1151169/2009-FCOMP-01-0124-FEDER-014433. 


\section{Bibliographic references}

(S/1999/944) Letter from the Secretary-General Addressed to the President of the Security Council - S/1999/944 3rd September 1999, (http://www.undemocracy.com/S-1999-944.pdf), [21st June 2011].

(S/1999/1025) Letter from the Secretary-General Addressed to the President of the Security Council-S/1999/1025 4th October 1999, (http://daccess-dds-ny.un.org/doc/UNDOC/GEN/ N99/285/78/PDF/N9928578.pdf?OpenElement), [21st June 2011].

(S/2004/888) Progress Report of the Secretary-General on the United Nations Mission of Support in East Timor - S/2004/888 9th November 2004, (http://daccess-dds-ny.un.org/ doc/UNDOC/GEN/N04/587/60/PDF/N0458760.pdf?OpenElement), [5th January 2012].

(S/2006/628) Report of the Secretary-General on Timor-Leste pursuant to Security Council Resolution 1690 (2006) - S/2006/628 8th August 2006, (http://www.un.org/ga/search/ view_doc.asp?symbol=S/2006/628), [3rd August 2011].

(S/RES/1246) UN Security Council Resolution 1246 - S/RES/1246 11th June 1999, (http:// daccess-dds-ny.un.org/doc/UNDOC/GEN/N99/174/13/PDF/N9917413.pdf?OpenElement), [20th June 2011].

(S/RES/1257) UN Security Council Resolution 1257 - S/RES/1257 3rd August 1999, (http:// daccess-dds-ny.un.org/doc/UNDOC/GEN/N99/226/69/PDF/N9922669.pdf?OpenElement), [20th June 2011].

(S/RES/1262) UN Security Council Resolution 1262 - S/RES/1262 27th August 1999, (http:// daccess-dds-ny.un.org/doc/UNDOC/GEN/N99/247/47/PDF/N9924747.pdf?OpenElement), [20th June 2011].

(S/RES/1264) UN Security Council Resolution 1264 - S/RES/1264 15th September 1999, (http://daccess-dds-ny.un.org/doc/UNDOC/GEN/N99/264/81/PDF/N9926481. pdf?OpenElement), [2nd August 2011].

(S/RES/1272) UN Security Council Resolution 1272 - S/RES/1272 25th October 1999, (http://daccess-dds-ny.un.org/doc/UNDOC/GEN/N99/312/77/PDF/N9931277. pdf?OpenElement), [23rd April 2010].

(S/RES/1410) UN Security Council Resolution 1410 - S/RES/1410 17th May 2002, (http:// www.unhchr.ch/Huridocda/Huridoca.nsf/(Symbol)/S.RES.1410+(2002).En?Opendocument), [2nd August 2011].

(S/RES/1480) UN Security Council Resolution 1480 - S/RES/1480 19th May 2003, (http://www.undemocracy.com/S-RES-1480(2003).pdf), [3rd August 2011].

(S/RES/1543) UN Security Council Resolution 1543 - S/RES/1543 14th May 2004, (http://www.worldlii.org/int/other/UNSCRsn/2004/22.pdf), [3rd August 2011].

(S/RES/1573) UN Security Council Resolution 1573 - S/RES/1573 16th November 2004, (http://www.undemocracy.com/S-RES-1573(2004).pdf), [3rd August 2011].

(S/RES/1599) UN Security Council Resolution 1599 - S/RES/1599 28th April 2005, (http://www.undemocracy.com/S-RES-1599(2005).pdf), [3rd August 2011].

(S/RES/1677) UN Security Council Resolution 1677 - S/RES/1677 12th May 2006, (http://www.undemocracy.com/S-RES-1677(2006).pdf), [3rd August 2011]. 
(S/RES/1690) UN Security Council Resolution 1690 - S/RES/1690 20th June 2006, (http://www.securitycouncilreport.org/atf/cf/\%7B65BFCF9B-6D27-4E9C-8CD3CF6E4FF96FF9\%7D/TL\%20SRES\%201690.pdf), [3rd August 2011].

(S/RES/1703) UN Security Council Resolution 1703 - S/RES/1703 18th August 2006, (http://www.un.org/ga/search/view_doc.asp?symbol=S/RES/1703(2006)), [3rd August 2011].

(S/RES/1704) UN Security Council Resolution 1704 - S/RES/1704 25th August 2006, (http://www.un.org/ga/search/view_doc.asp?symbol=S/RES/1704(2006)), [3rd August 2011].

(S/RES/1745) UN Security Council Resolution 1745 - S/RES/1745 22nd February 2007, (http://www.un.org/ga/search/view_doc.asp?symbol=S/RES/1745(2007)), [3rd August 2011].

(S/RES/1802) UN Security Council Resolution 1802 - S/RES/1802 25th February 2008, (http://daccess-dds-ny.un.org/doc/UNDOC/GEN/N08/251/41/PDF/N0825141. pdf?OpenElement), [20th March 2011].

(S/RES/1867) UN Security Council Resolution 1867 - S/RES/1867 26th February 2009, (http://daccess-dds-ny.un.org/doc/UNDOC/GEN/N09/250/24/PDF/N0925024. pdf?OpenElement), [3rd August 2011].

(S/RES/1912) UN Security Council Resolution 1912 - S/RES/1912 26th February 2010, (http://daccess-dds-ny.un.org/doc/UNDOC/GEN/N10/253/13/PDF/N1025313. pdf?OpenElement), [3rd August 2011].

(S/RES/1969) UN Security Council Resolution 1969 - S/RES/1969 24th February 2011, (http://daccess-dds-ny.un.org/doc/UNDOC/GEN/N11/242/86/PDF/N1124286. pdf?OpenElement), [3rd August 2011].

(S/RES/2037) UN Security Council Resolution 2037 - S/RES/2037 23rd February 2012, (http://daccess-dds-ny.un.org/doc/UNDOC/GEN/N12/240/01/PDF/N1224001. pdf?OpenElement), [28th February 2012].

Beauvais, Joel C. (2001) "Benevolent Despotism: A Critique of UN State-Building in East Timor" New York University Journal of International Law and Politics. 33 (4), 1101-11078.

Bickerton, Christopher (2007) "State-Building: Exporting State-Failure” in Bickerton, Cunliffe \& Gourevitch (Ed.) Politics without Sovereignty: a critique of Contemporary International Relations. London: University College London Press, 93-111.

Blanco, Ramon (2014) “Del Mantenimiento de la Paz al Proceso de Formación del Estado: Un Esbozo de los Esfuerzos de la ONU para la Paz Internacional” Foro Internacional. 216 (2), 266-318.

Boege, Volker; Brown, M. Anne; Clements, Kevin P.; Nolan, Anna (2008) "States Emerging from Hybrid Political Orders - Pacific Experiences" The Australian Centre for Peace and Conflict Studies - Occasional Papers Series. 11 (September), i-41.

Boege, Volker; Brown, M. Anne; Clements, Kevin P.; Nolan, Anna (2009) “On Hybrid Political Orders and Emerging States: What is Failing - States in the Global South or Research and Politics in the West?” The Berghof Handbook Dialogue Series. (8), 15-36.

Boege, Volker; Brown, M. Anne; Clements, Kevin P.; Nolan, Anna (2010) "Challenging Statebuilding as Peacebuilding - Working with Hybrid Political Orders to Build Peace" in Richmond, Oliver (Ed.) Palgrave Advances in Peacebuilding - Critical Developments and Approaches. London and New York: Palgrave, 100-115. 
Carvalho, Maria José Albarran de (2001) "Panorama Linguístico de Timor. Identidade Regional, Nacional e Pessoal” Camóes - Revista de Letras e Culturas Lusófonas. 14 (Julho-Setembro), 65-79. Chandler, David (2006) The Empire in Denial-The Politics of State-building. London: Pluto Press. Chandler, David (2008) "Introduction" in Chandler, David (Ed.) Statebuilding and Intervention: Policies, Practices and Paradigms. London and New York: Routledge, 1-16.

Chesterman, Simon (2005) "From State Failure to State-Building: Problems and Prospects for a United Nations Peacebuilding Commission" Journal of International Law and International Relations. 2 (1), 155-175.

Chopra, Jarat (2002) “Building State Failure in East Timor" Development and Change. 33 (5), 979-1000.

CIGI, The Centre for International Governance Innovation (2009) Security Sector Reform Monitor - Timor-Leste Security Sector Reform Monitor No. 1, December 2009, (http:// fundasaunmahein.files.wordpress.com/2009/12/ssrm-east-timor-1.pdf), [August 01st 2012].

Curtain, Richard (2006) Crisis in Timor Leste: Looking Beyond the Surface Reality for Causes and Solutions State, Society and Governance in Melanesia Project, 2006, (http://rspas.anu.edu. au/papers/melanesia/working_papers/06_01wp_Curtain.pdf), [August 3rd 2011].

David, Charles-Philippe (1999) "Does Peacebuilding Build Peace?: Liberal (Mis)steps in the Peace Process” Security Dialogue. 30 (1), 25-41.

Doyle, Michael W.; Sambanis, Nicholas (2006) Making War and Building Peace: United Nations Peace Operations. New Jersey: Princeton University Press.

Duffield, Mark (2001) Global Governance and the New Wars. London: Zed Books.

Encarnación, Omar G. (2005) “The Follies of Democratic Imperialism” World Policy Journal. 22 (1), 47-60.

Englebert, Pierre; Tull, Denis M. (2008) "Postconflict Reconstruction in Africa: Flawed Ideas about Failed States” International Security. 32 (4), 106-139.

Fearon, James; Laitin, David (2004) "Neotrusteeship and the Problem of Weak States" International Security. 28 (4), 5-43.

Fortna, Vginia Page (2008) Does Peacekeeping Work? Shaping Belligerents' Choices after Civil War. New Jersey: Princeton University Press.

Gilligan, Michael J.; Sergenti, Ernest J. (2008) “Do UN Interventions Cause Peace? Using Matching to Improve Causal Inference" Quarterly Journal of Political Science. 3 (2), 89-122.

Ginty, Roger Mac (2008) "Indigenous Peace-Making Versus the Liberal Peace" Cooperation and Conflict. 43 (2), 139-163.

Goldstone, Anthony (2004) "UNTAET with Hindsight: The Peculiarities of Politics in an Incomplete State” Global Governance. 10 83-98.

Gürkaynak, Esra Çuhadar; Dayton, Bruce; Paffenholz, Thania (2009) "Evaluation in Conflict Resolution and Peacebuilding" in Sandole, Dennis J. D.; Byrne, Sean; Sandole-Staroste, Ingrid; Senehi, Jessica (Eds.), Handbook of Conflict Analysis and Resolution. Oxon: Routledge, 286-299.

ICG, International Crisis Group (2006) Resolving Timor-Leste's Crisis Asia Report No. 120, 10 October 2006, (http://www.crisisgroup.org/ //media/Files/asia/south-east-asia/timorleste/120_resolving_timor_lestes_crisis.pdf), [September 20th 2010]. 
ICG, International Crisis Group (2008) Timor-Leste: Security Sector Reform Asian Report No. 143, 17 January 2008, (http://www.crisisgroup.org/ /media/Files/asia/south-east-asia/ timor-leste/143_timor_leste__security_sector_reform.pdf), [September 20th 2010].

Ignatieff, Michael (2003) Empire Lite: Nation Building in Bosnia, Kosovo, Afghanistan. London: Vintage.

Jahn, Beate (2007a) "The Tragedy of Liberal Diplomacy: Democratization, Intervention, Statebuilding (Part I)" Journal of Intervention and Statebuilding. 1 (1), 87-106.

Jahn, Beate (2007b) “The Tragedy of Liberal Diplomacy: Democratization, Intervention, Statebuilding (Part II)" Journal of Intervention and Statebuilding. 1 (2), 211-229.

Kenkel, Kai Michael (2013) "Five Generations of Peace Operations: From the "Thin Blue Line" to "Painting a Country Blue" "Revista Brasileira de Politica Internacional. 56 (2), 122-143.

Kingsbury, Damien (2009) East Timor - The Price of Liberty. New York: Palgrave Macmillan.

Lijn, Jaïr van der (2009) "If only There Were a Blueprint! Factors for Success and Failure of UN Peace-Building Operations” Journal of International Peacekeeping. 13 (1-2), 45-71.

Luttwak, Edward N. (1999) "Give War a Chance” Foreign Affairs. 78 (4), 36-44.

Magalhães, António Barbedo de (2007) Timor-Leste - Interesses Internacionais e Actores Locais - 3 Volumes. Porto: Afrontamento.

Mansfield, Edward; Snyder, Jack (2005) Electing to Fight: Why Emerging Democracies Go to War. Cambridge: MIT Press.

Martin, Ian (2001) Self-Determination in East Timor: The United Nations, the Ballot, and International Intervention. Boulder: Lynner Rienner Publishers.

Martin, Ian; Mayer-Rieckh, Alexander (2005) “The United Nations and East Timor: From Self-Determination to State-Building” International Peacekeeping. 12 (1), 125-145.

Miguel, Edward (2007) "Poverty and Violence: An Overview of Recent Research and Implications for Foreign Aid" in Brainard, Lael; Chollet, Derek (Eds.), Too Poor for Peace?: Global Poverty, Conflict, and Security in the 21st Century. Washington D.C.: Brookings Institution Press, 50-59.

Newman, Edward; Paris, Roland; Richmond, Oliver P. (2009) "Introduction" in Newman, Edward; Paris, Roland; Richmond, Oliver P. (Eds.), New Perspectives on Liberal Peacebuilding. Tokyo, New York, Paris: United Nations University Press, 3-25.

Ottaway, Marina (2002) "Rebuilding State Institutions in Collapsed States" Development and Change. 33 (5), 1001-1023.

Paris, Roland (2002) "International Peacebuilding and the 'Mission Civilisatrice" Review of International Studies. 28 (4), 637-656.

Paris, Roland (2004) At War's End: Building Peace After Civil Conflict. Cambridge: Cambridge University Press.

Paris, Roland (2009) "Understanding the "Coodination Problem" in Postwar Statebuilding" in Paris, Roland; Sisk, Timothy (Eds.), The Dilemmas of Statebuilding: Confronting the Contradictions of Postwar Peace Operations. New York: Routledge, 53-78.

Paris, Roland (2010) “Saving Liberal Peacebuilding” Review of International Studies. 36 (2), 337-365. 
Paris, Roland; Sisk, Timothy (Eds.) (2009a) The Dilemmas of Statebuilding: Confronting the Contradictions of Postwar Peace Operations. New York: Routledge.

Paris, Roland; Sisk, Timothy (2009b) "Introduction: Understanding the Contradictions of Postwar Statebuilding" in Paris, Roland; Sisk, Timothy (Eds.), The Dilemmas of Statebuilding: Confronting the Contradictions of Postwar Peace Operations. New York: Routledge, 1-20.

Pouligny, Beatrice (2006) Peace Operations Seen From Below - UN Missions and Local People. C. Hurst \& Co Publishers.

Pugh, Michael (2005) "The Political Economy of Peacebuilding: A Critical Theory Perspective" International Journal of Peace Studies. 10 (2), 23-42.

Pureza, José Manuel; Simões, Mónica Rafael; José, André Cristiano; Marcelino, Carla (2007) "As Novas Operações de Paz das Nações Unidas. Os casos de Angola, Timor-Leste e Moçambique" Oficina do CES no 290. Novembro 1-34.

Ramsbotham, Oliver (2000) "Reflections on UN post-settlement peacebuilding" International Peacekeeping. 7 (1), 169-189.

Rice, Susan E. (2007) "Poverty Breeds Insecurity" in Brainard, Lael; Chollet, Derek (Eds.), Too Poor for Peace?: Global Poverty, Conflict, and Security in the 21st Century. Washington D.C.: Brookings Institution Press, 31-49.

Richmond, Oliver (2004) "The Globalization of Responses to Conflict and the Peacebuilding Consensus" Cooperation and Conflict 39 (2), 129-150.

Richmond, Oliver (2006) "The Problem of Peace: Understanding the 'Liberal Peace" Conflict, Security \& Development. 6 (3), 291-314.

Richmond, Oliver (2007) The Transformation of Peace. New York: Palgrave Macmillan.

Richmond, Oliver (2009) "A post-liberal peace: Eirenism and the everyday" Review of International Studies. 35 (3), 557-580.

Richmond, Oliver (2011) A Post-Liberal Peace. Abingdon and New York: Routledge.

Richmond, Oliver; Franks, Jason (2008) “Liberal Peacebuilding in Timor Leste: The Emperor’s New Clothes?” International Peacekeeping. 15 (2), 185-200.

Richmond, Oliver; Franks, Jason (2009) Liberal Peace Transitions - Between Statebuilding and Peacebuilding. Edinburgh: Edinburgh University Press.

Samuels, Kirsti; Einsiedel, Sebastian von (2003) The Future of UN State-Building: Strategic and Operational Challenges and the Legacy of Iraq International Peace Academy - Policy Report, 14-16th November 2003, (http://www.ipinst.org/media/pdf/publications/future_of_un_state_ building.pdf), [28th December 2010].

Sen, Amartya (2008) "Violence, Identity and Poverty" Journal of Peace Research. 45 (1), 5-15.

Snyder, Jack (2000) From Voting to Violence: Democratization and Nationalist Conflict. New York: Norton.

STAE, Secretariado Técnico de Administração Eleitoral (2007a) Eleiçóes Parlamentares 2007 (Resultado) NA, (http://www.stae.tl/elections/2007/parliament/results/), [August 09th 2012].

STAE, Secretariado Técnico de Administração Eleitoral (2007b) Eleições Presidenciais 2007 (Resultado 2a volta) NA, (http://www.stae.tl/elections/2007/president/results/second_round/), [August 09th 2012]. 
STAE, Secretariado Técnico de Administração Eleitoral (2012) Rezultadu Provizorio Eleisaun Prezidensial 2012 Segundo Volta NA, (http://www.stae.tl/elections/2012/rezultado/segunda/), [August 09th 2012].

Suhrke, Astri (2001) "Peacekeepers as nation-builders: Dilemmas of the UN in East Timor" International Peacekeeping. 8 (4), 1-20.

Taylor, Ian (2010) "Liberal Peace, Liberal Imperialism: A Gramscian Critique" in Richmond, Oliver (Ed.) Palgrave Advances in Peacebuilding. London: Palgrave Macmillan, 154-174.

Teles, Patrícia Galvão (1999) "Autodeterminação em Timor Leste: dos acordos de Nova Iorque à consulta popular de 30 de Agosto de 1999" Boletim Documentação e Direito Comparado. 79-80 (Maio), 379-423.

Traub, James (2000) "Inventing East Timor" Foreign Affairs. 79 (4), 74-89.

UN, United Nations Peacekeeping Department (2008) United Nations Peacekeeping Operations Principles and Guidelines (http://pbpu.unlb.org/PBPS/Library/Capstone_Doctrine_ENG. pdf), [04th May 2009].

UNDP, United Nations Development Program (2014) Human Development Report 2014: Sustaining Human Progress Reducing Vulnerabilities and Building Resilience. New York: United Nations Development Programme.

\author{
Submitted on February 9, 2015 \\ Accepted on March 13, 2015
}

\begin{abstract}
This paper brings a comprehensive analysis of the peacebuilding process conducted by the UN in Timor-Leste. Drawing on fieldwork, interviews, and secondary sources, the paper brings light to the main fragilities of this process. Firstly, the paper briefly outlines the scholarly debate around UN peacebuilding process. Then, the paper brings an overview of the UN missions deployed to Timor-Leste. Finally, the paper identifies the major limitations of such engagement. By highlighting the main flaws of this peacebuilding process, the paper opens the space for (re)thinking alternative ways of building peace in post-conflict scenarios.
\end{abstract}

Keywords: post-conflict reconstruction; peacebuilding; United Nations; Timor-Leste.

\title{
Resumo
}

Este artigo traz uma análise alargada do processo de construção da paz conduzido pela ONU em Timor-Leste. Baseando-se em trabalho de campo, entrevistas, e fontes secundárias, este artigo ilumina as principais fragilidades deste processo. Primeiramente, o artigo brevemente delineia o debate acadêmico em torno dos processos de construção da paz liderados pela ONU. Em seguida, o artigo traz uma visão global das missões da ONU destacadas ao país. Finalmente, o artigo identifica as principais limitações deste envolvimento. lluminando as principais falhas deste processo de peacebuilding, o artigo abre o espaço para (re)pensar modos alternativos de construir a paz em cenários pós-conflito.

Palavras-chave: reconstrução pós-conflito; construção da paz; Organização das Nações Unidas; Timor Leste. 